\title{
Peptidergic Activation of Locomotor Pattern Generators in the Neonatal Spinal Cord
}

\author{
Selina A. Pearson, ${ }^{1,2}$ Abdeslam Mouihate, ${ }^{1,2}$ Quentin J. Pittman, ${ }^{1,2}$ and Patrick J. Whelan ${ }^{1,2,3}$ \\ ${ }^{1}$ Neuroscience Research Group and Departments of ${ }^{2}$ Physiology and Biophysics and ${ }^{3}$ Clinical Neurosciences, University of Calgary, Calgary, Alberta \\ T2N 4N1, Canada
}

The development of motor networks in the spinal cord is partly activity-dependent. We have observed receptor-mediated excitatory effects of two peptides, arginine vasopressin (AVP) and oxytocin (OXT), on motor network activity in the neonate. With the use of an en bloc in vitro preparation of mouse spinal cord (2-3 d old), which either was isolated completely or had muscles of the hindlimb left intact, we show that the bath application of AVP or OXT can evoke an increase in population bursting of motoneurons recorded from the lumbar ventral roots. By using antagonists for AVP and OXT, we found that these peptides were binding primarily to $\mathrm{V}_{1 \mathrm{a}}$ and $0 \mathrm{XT}$ receptors, respectively. Western blot analysis revealed a $48 \mathrm{kDa} \mathrm{V}_{1 \mathrm{a}}$ and a $55 \mathrm{kDa}$ OXT receptor immunoreactive band that was expressed in tissue obtained from L1-L6 sections of spinal cord. AVP, but not OXT, could, on occasion, evoke sustained periods of locomotor-like activity. In addition, when we applied AVP or OXT in combination with a $5-\mathrm{HT}_{2}$ agonist, bouts of locomotor-like activity could be observed in a majority of preparations. Collectively, these data point to a novel role for AVP and OXT in the activation of spinal motor networks.

Key words: peptides; CPG; networks; spinal cord; motor; vasopressin; oxytocin

\section{Introduction}

During the first 3 postnatal weeks rodents show a gradual expression of motor behaviors such as weight-bearing locomotion and postural reflexes (Clarac et al., 1998). These developmental changes in motor performance are accompanied by the expression of transient inappropriate synapses (Seebach and ZiskindConhaim, 1994), the maturation of descending pathways that control posture and locomotion (Clarac et al., 1998), and the transient upregulation of multiple receptor types for fast classical (GluR1, NMDA, AMPA, GABA) (Kalb et al., 1992; Ma et al., 1994; Jakowec et al., 1995; Stegenga and Kalb, 2001; Inglis et al., 2002) and peptidergic ( $\mathrm{V}_{1 \mathrm{a}}$ and oxytocin) neurotransmitters (Tribollet et al., 1989, 1991; Reiter et al., 1994).

A general consensus is emerging that in diverse systems of the brain, including the hippocampus (Ben Ari, 2001), spinal cord (O'Donovan et al., 1998) and retina (Feller, 1999), activity plays an important role in the normal development of networks. A novel way in which spinal networks could be activated perinatally is by the neurohypophysial peptides arginine vasopressin (AVP) and oxytocin (OXT). In the adult rat most oxytocinergic and vasopressinergic fibers in the spinal cord originate in the paraventricular hypothalamic nucleus (PVN) (Swanson and McKellar, 1979; Hawthorn et al., 1980; Sawchenko and Swanson, 1982;

Received May 21, 2003; revised Sept. 18, 2003; accepted Sept. 19, 2003.

This research was supported by grants from the Natural Sciences and Engineering Research Council and the Canadian Institutes of Health Research. P.J.W. is a Heart and Stroke of Canada Scholar. Q.J.P. is an Alberta Heritage Foundation for Medical Research Medical Scientist. We gratefully acknowledge the technical assistance of Michelle Madriaga and the gift of SR 49059 from Sanofi-Synthelabo.

Correspondence should be addressed to PatrickJ. Whelan, Departments of Physiology and Biophysics and Clinical Neurosciences, Neuroscience Research Group, 3330 Hospital Drive Northwest, Calgary, Alberta T2N 4N1, Canada. E-mail:whelan@ucalgary.ca.

Copyright $\odot 2003$ Society for Neuroscience 0270-6474/03/2310154-10\$15.00/0
Hallbeck and Blomqvist, 1999; Motawei et al., 1999; Hallbeck et al., 2001). Fibers from the PVN arrive in the thoracic spinal cord before birth and in the lumbar spinal cord of the neonatal rat at postnatal day 2 (P2) (Leong et al., 1984; Kudo et al., 1993; Lakke, 1997). In principle, these peptides are ideally placed to influence spinal network activity. In the neonatal rat spinal cord both AVP and OXT binding sites are expressed densely, declining in number at approximately the time of weaning at P21 (Tribollet et al., 1989, 1991; Liu et al., 2003). These receptors appear to be functional, because both of these peptides have a variety of electrophysiological actions in the neonatal spinal cord (Suzue et al., 1981; Kolaj and Renaud, 1998; Oz et al., 2001; Liu et al., 2003). OXT depolarizes sympathetic preganglionic neurons (Sermasi and Coote, 1994; Desaulles et al., 1995) and modulates glutamatergic transmission between cultured dorsal horn neurons (Jo et al., 1998). AVP depolarizes nearly all lateral and ventral horn neurons tested in neonatal rat spinal cord slices (Kolaj and Renaud, 1998; Oz et al., 2001), consistent with the widespread expression of receptors reported to exist at this time (Tribollet et al., 1991; Reiter et al., 1994; Liu et al., 2003).

The proliferation of receptors within the spinal cord throughout the neonatal period suggests that OXT and AVP may activate or modulate network activity. In this study we make use of an isolated mouse spinal cord preparation (Whelan et al., 2000) to examine the functional effects of AVP and OXT on spinal networks. We demonstrate that AVP or OXT, alone or in concert with other neuromodulators, can activate networks of neurons to generate locomotor-like activity in the neonatal spinal cord. This suggests a possible new role for AVP and OXT in the developing motor network of the neonatal spinal cord.

Part of this work has been presented in abstract form (Pearson et al., 2002). 


\section{Materials and Methods}

Procedures were approved by the University of Calgary Animal Care Committee. Experiments were performed on Swiss Webster mice (Charles River Laboratories, Wilmington, MA) 2-3 d old (P2-P3; weight, $1.80-3.60 \mathrm{gm} ; n=81$ ). The animals were anesthetized by hypothermia. Animals were decapitated rapidly and eviscerated; the remaining tissue was placed in a dissection chamber filled with oxygenated (95\% $\mathrm{O}_{2} / 5 \% \mathrm{CO}_{2}$ ) low-calcium, high-magnesium, artificial CSF [ACSF; concentration (in mM): $128 \mathrm{NaCl}, 4 \mathrm{KCl}, 0.1 \mathrm{CaCl}_{2}, 2 \mathrm{MgSO}_{4}, 0.5 \mathrm{NaH}_{2} \mathrm{PO}_{4}$, $21 \mathrm{NaHCO}_{3}, 30$ D-glucose] kept at $4^{\circ} \mathrm{C}$ throughout the dissection. A ventral laminectomy exposed the cord, and the ventral and dorsal roots were cut. The spinal cord was transected at $\mathrm{T} 1-\mathrm{T} 3$ and $\mathrm{S} 2-\mathrm{S} 3$ and gently removed from the vertebral column. The ACSF containing the isolated spinal cord was allowed to warm up to room temperature; the preparation was transferred to the recording chamber and superfused with oxygenated ACSF [concentration (in $\mathrm{mm}$ ): $128 \mathrm{NaCl}, 4 \mathrm{KCl}, 1.5 \mathrm{CaCl}_{2}, 1$ $\mathrm{MgSO}_{4}, 0.5 \mathrm{NaH}_{2} \mathrm{PO}_{4}, 21 \mathrm{NaHCO}_{3}, 30$ D-glucose]. Then the bath solution was heated gradually from room temperature $\left(\sim 20-22^{\circ} \mathrm{C}\right)$ to $27^{\circ} \mathrm{C}$.

In some experiments we recorded from the common peroneal (CP) nerve or hindlimb muscles [tibialis anterior (TA) and/or quadriceps and/or triceps surae (TS)]. In these preparations a ventral laminectomy was performed to the level of S3. The spinal cord was transected at the level of T5-T7, and the dorsal and ventral roots were cut up to T12. The cord was removed from the vertebral column to T13, and nonspinal cord tissue rostral to $\mathrm{T} 12$ was discarded. We then performed a dorsal laminectomy from T13 to S1-S3. Then the sciatic nerve along with the CP nerve was freed for nerve recordings, or the hindlimb muscles were exposed for electromyogram (EMG) recordings.

Electrophysiological recordings. Population motoneuron bursting activity was recorded with plastic suction electrodes into which segmental L2 and L5 ventral roots were drawn. Generally, recordings were made from two roots from each spinal cord preparation. For locomotor studies, neurogram recordings also were obtained from L2 and L5 segmental ventral roots. In selected experiments electroneurogram (ENG) recordings from the $\mathrm{CP}$ nerve were obtained by using suction electrodes (Whelan et al., 2000). EMG recordings were obtained from the hindlimb muscles by inserting bipolar platinum-iridium fine wires ( $50 \mu \mathrm{m}$ diameter) into the muscle belly or by using suction electrodes attached to the muscle. Electrophysiological recordings were amplified (1000-20,000 times for ENG; 500-5000 times for EMG), bandpass-filtered (100 Hz-1 $\mathrm{kHz}$ ), and digitized at $2 \mathrm{kHz}$ (Axon Instruments Digidata 1320, Union City, CA) for future analysis.

General protocol. The preparations were allowed to equilibrate in the recording chamber for $\sim 1 \mathrm{hr}$. Then $10 \mathrm{~min}$ of control baseline activity was recorded in the presence of oxygenated ACSF; either OXT or AVP (Bachem, Torrance, CA) was added (bath concentration, 0.3-300 nM), to determine dose-response relationships. The selective nonpeptide $\mathrm{V}_{1 \mathrm{a}}$ receptor antagonist SR 49059 (300 nM; Sanofi-Synthelabo, Toulouse, France) and the selective peptide OXT receptor antagonist $\left[\mathrm{d}\left(\mathrm{CH}_{2}\right)_{5}{ }^{1}\right.$, Tyr $(\mathrm{Me})^{2}, \mathrm{Thr}^{4}, \mathrm{Orn}^{8}$, des-Gly- $\left.\mathrm{NH}_{2}{ }^{9}\right]$-vasotocin (300 nm; Bachem) were used. The antagonists were used at 10 times the concentration of the agonist.

Where the antagonists were used, first a response to $30 \mathrm{~nm}$ of the peptide agonist was recorded. Then $50 \mathrm{~min}$ later the antagonist was applied at a concentration of $300 \mathrm{~nm}, 5 \mathrm{~min}$ before the agonist was reapplied. The agonist was applied for $5 \mathrm{~min}$ and finally washed out with ACSF.

In experiments in which the $5-\mathrm{HT}_{2}$ receptor agonist $\alpha$-methyl-5hydroxytriptamine ( $\alpha$-m-5-HT; Sigma, St. Louis, MO) was used with AVP or OXT, $0.5-1.0 \mu \mathrm{M} \alpha-\mathrm{m}-5$-HT was added to the bath first and left for $30 \mathrm{~min}$ for the effects to stabilize. These concentration ranges did not evoke locomotor-like activity alone. Then $50 \mathrm{~nm}$ AVP or $100 \mathrm{~nm}$ OXT was added to the bath, and the responses were recorded. In control experiments the preparation was left in the presence of $0.5 \mu \mathrm{M} \alpha-\mathrm{m}-5-\mathrm{HT}$ for 1 $\mathrm{hr}$, and no AVP or OXT was added.

Data analysis. Data were rectified digitally, integrated, and then analyzed by using custom written programs (MatLab, MathWorks, Natick, MA). A ratio method was used to compare the responses obtained after drug addition with control conditions 5 min before drug addition. The effects of AVP or OXT on locomotor-like activity were quantified via time series analysis. Time series analysis was performed by taking intervals of $60 \mathrm{sec}$ of raw data, rectifying the data, applying a low-pass filter, and resampling at $100 \mathrm{~Hz}$. Means were subtracted from the processed data and smoothed further with a digital filter (Savitzky-Golay, thirdorder polynomial operating over 13 points). Cross- and autocorrelograms then were calculated, and the quality of the rhythm was assessed by measuring the correlation coefficients for L2 right (L2 R) and L2 left (L2 $\mathrm{L})$ ventral root bursts and the L2 L and L5 L ventral root bursts. The cycle periods for the resultant rhythm were calculated by measuring the number of lags (each lag $=50 \mathrm{msec}$ ) from one peak to the next from the autocorrelogram (see Fig. 6). The phase delay between ventral root bursts was obtained from the cross-correlogram and was defined as the number of lags from lag 0 to the next positive peak, converted to seconds, and divided by the cycle period (obtained from the autocorrelograms; see Fig. 6 ). Data were expressed as the mean \pm SEM and analyzed by paired and unpaired Student's $t$ tests if the data were distributed normally. If data were not distributed normally, the data were analyzed with a Wilcoxon Signed Rank test. Multiple data points were analyzed with a one-way ANOVA, followed by a Tukey post hoc test to detect significant differences.

Protein extraction. Animals at P3 $(n=3)$ were anesthetized as previously described, decapitated, and eviscerated to expose the descending aorta. Animals were perfused through the descending aorta with lowcalcium, high-magnesium ACSF cooled to $4^{\circ} \mathrm{C}$. The lumbar spinal cord was exposed by ventral laminectomy from L1 to L6, snap-frozen in liquid nitrogen, and stored at $-80^{\circ} \mathrm{C}$ until use. The spinal cord fragment was put in lysis buffer [containing (in mM): 20 MOPS, $4.5 \mathrm{Mg}\left(\mathrm{C}_{2} \mathrm{H}_{3} \mathrm{O}_{2}\right)_{2}, 150$ $\mathrm{KCl}$ plus $1 \%$ Triton $\mathrm{X}-100$ ] supplemented with protease inhibitor tablets (Roche Diagnostics GmbH, Mannheim, Germany) plus $1 \mathrm{~mm}$ sodium vanadate (Sigma) and $500 \mu \mathrm{m}$ phenyl-methyl-sulfonyl-fluoride (Boehringer Mannheim, Indianapolis, IN). After mechanical dissociation of the tissue, the protein levels were assayed by using a bicinchoninic acid protein assay (Pierce Rockford, IL). The proteins then were put in a sample buffer composed of 125 mm Tris-HCl (Sigma), 3\% SDS (Bio-Rad Laboratories, Richmond, CA), 20\% glycerol (Sigma), bromophenol blue (Sigma), $20 \% \beta$-mercaptoethanol (BDH Chemicals, Poole, UK), boiled for 5 min, and stored at $-20^{\circ} \mathrm{C}$ until Western blot analysis.

Western blot analysis. Proteins ( $15 \mu \mathrm{g} /$ well) were separated on $10 \%$ SDS-PAGE with constant current of $30 \mathrm{~mA} /$ gel, using gels that were 1.2 $\mathrm{mm}$ thick. Molecular weight markers (Bio-Rad) were used in each individual gel. At the end of separation, the proteins were transferred onto nitrocellulose membrane for $2 \mathrm{hr}$ under a constant current $\left(1.2 \mathrm{~mA} / \mathrm{cm}^{2}\right.$ of gel surface), using a transfer buffer containing $20 \%$ methanol, $50 \mathrm{~mm}$ Trizma base (Sigma), $40 \mathrm{~mm}$ glycine (Sigma), 0.04\% SDS (Bio-Rad). Membranes then were incubated for $2 \mathrm{hr}$ at room temperature with $10 \%$ fat-free milk in Tris-buffered saline containing Tween-20 (TBS-T) composed of $20 \mathrm{~mm}$ Trizma-base (Sigma), $0.15 \mathrm{~m}$ sodium chloride, $0.1 \%$ polyoxyethylene-sorbitan monolaurate (Sigma). A well characterized rabbit $\mathrm{V}_{1 \mathrm{a}}$ receptor antibody $(1 \mu \mathrm{g} / \mathrm{ml}$; Chemicon, Temecula, CA) (Hurbin et al., 2002; Clerget-Froidevaux and Pittman, 2003) or OXT receptor antibody ( $5 \mu \mathrm{g} / \mathrm{ml}$; RDI, Flanders, NJ) (Mukaddam-Daher et al., 2002) were used. After $2 \mathrm{hr}$ of incubation with the primary antibody the membrane was washed with TBS-T and incubated with goat antirabbit IgG conjugated with horseradish peroxidase (1:4000) (Santa Cruz Biotechnology, Santa Cruz, CA) for $1 \mathrm{hr}$ at room temperature. A chemiluminescence substrate was applied to the membrane (ECL Kit, Amersham Biosciences, Buckinghamshire, UK), and protein bands were visualized with Kodak X-OMAT film (Eastman Kodak, Rochester, NY).

\section{Results}

\section{General remarks}

Bath application of either OXT or AVP caused an increase in the bursting discharge recorded from lumbar ventral roots (L2-L5) in all of the spinal cords that were tested $[n=33$ (AVP), 24 (OXT) ]. The amplitude of the rectified discharge reached a peak 
$\mathrm{Ai}$

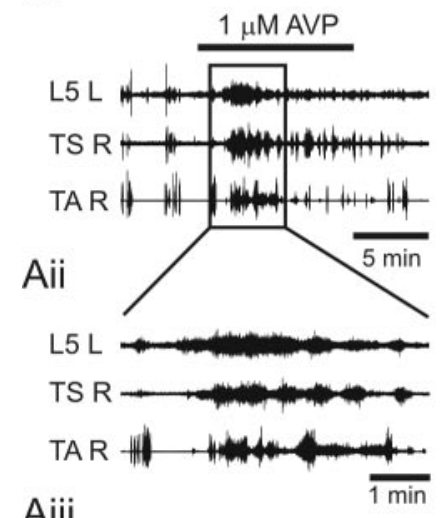

Aiii
$\mathrm{Bi}$

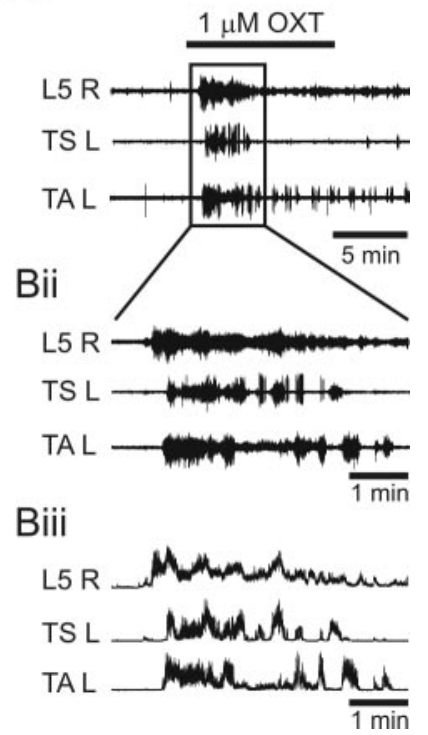

$\mathrm{Ai}$

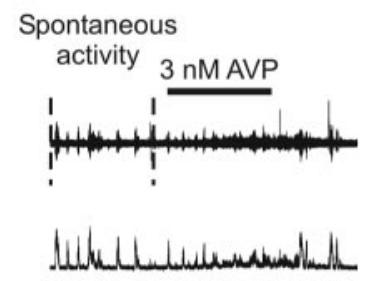

Aii
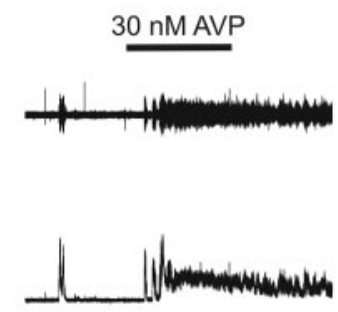

Aiii

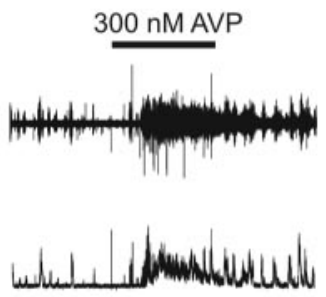

$\mathrm{Bi}$

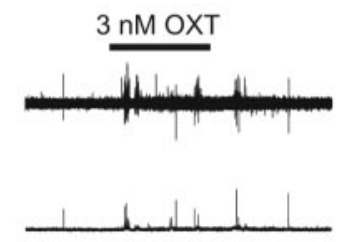

Bii

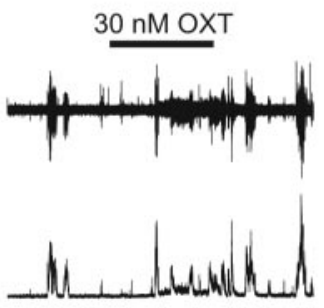

Biii

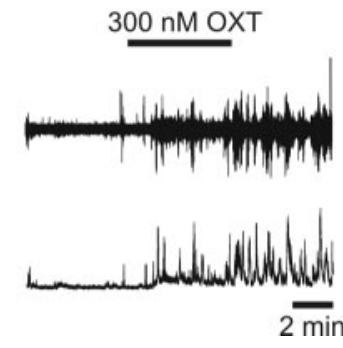

between 1 and 6 min after drug application and declined in amplitude before washout.

\section{EMG responses}

To establish that somatic motoneurons were being activated, EMGs were recorded from the TA $(n=8)$, quadriceps $(n=5)$, or TS muscles $(n=2)$, or in preliminary experiments ENG discharge was recorded from the CP nerve ( $n=3$; data not shown). These experiments used an in vitro spinal cord preparation in which a single hindlimb was left attached. In the majority of cases the bath application of $300 \mathrm{~nm}-1 \mu \mathrm{M}$ AVP ( 8 of 9 ) or OXT ( 5 of 7) caused an increase in the burst discharge recorded from both the L4/L5 ventral roots and the hindlimb EMGs (quadriceps, TA, and TS). An example is shown in Figure 1 in which EMG responses were recorded from the TS (ankle extensor) and TA (ankle flexor) muscles by using implanted fine-wire electrodes. The onsets of the hindlimb EMG responses after the application of AVP (Fig. $1 A$ ) or OXT (Fig. $1 B$ ) were at times delayed respective to the onset of the ventral root response. Although differences in the bursting behavior of individual muscles could be detected (Fig. $1 \mathrm{Aii}, \mathrm{Bii})$, generally, the bath application of either peptide caused tonic bursting similar to activity from ventral roots. As can be appreciated from Figure 1, $A$ and $B$, the overall onset and duration of the EMG responses closely matched the ventral root responses. Preliminary experiments $(n=3)$ in which neurogram responses from the $\mathrm{CP}$ nerve were recorded after the bath application of either OXT or AVP showed increases in discharge similar to the EMG recordings. For the remainder of the experiments we used an isolated spinal cord preparation in which neurogram recordings were obtained from the ventral roots. The viability of these isolated preparations is greater than the leg-attached preparation; thus they were better suited for experiments in which more complicated protocols were called for.

ure 2. A 5 min bath application of AVP and OXT increases neuronal activity in a dosedependent manner. Ai-Biii, Raw neurogram data showing bursting discharge from the $\mathrm{L} 2$ ventral root (top traces) and rectified and low-pass-filtered ( $5 \mathrm{~Hz}$ Gaussian) data (bottom traces). $A i-A i i i$, Traces show the increase in bursting activity after the bath application of $3 \mathrm{~nm}(A i)$, $30 \mathrm{~nm}$ (Aii), and $300 \mathrm{~nm}$ (Aiii) AVP. Bi-Biii, Traces show the increase in bursting activity after the bath application of $3 \mathrm{~nm}(B i), 30 \mathrm{~nm}$ (Bii), or $300 \mathrm{~nm}$ (Biii) OXT.

\section{Dose-response}

Bath-applied AVP or OXT produced a dose-dependent increase in population bursting activity recorded from ventral roots (Fig. 2). Response latency varied from $30 \mathrm{sec}$ to $3 \mathrm{~min}$, depending on the preparation and the concentration of bath-applied peptide.

Responses were quantified by calculating the integrated response for $5 \mathrm{~min}$ before (baseline) and after application of the peptide (response) and taking a ratio of these two values. We first determined whether sequential doses of the peptides could be applied to the cord without desensitization. Preliminary experiments ( $n=5$ AVP; $n=3$ OXT) revealed that successive applications of peptide, if separated by a washout time of $50 \mathrm{~min}$, resulted in identical responses. All experiments thus were performed with a minimum of 50 min latency between any successive peptide or drug application. Figure 3 illustrates the mean increase in response ratios for both AVP and OXT calculated from L2 ventral root data. A significant increase in response ratios was obtained when concentrations of $30 \mathrm{~nm}$ AVP or greater were applied to the bath (ANOVA, $p<0.001 ; n=5-7$ preparations per concentration; Fig. $3 A$ ). Responses recorded from the L5 ventral root were qualitatively similar (data not shown), except that greater concentrations of drug ( $\geq 100 \mathrm{nM}$ ) were required to produce a significant increase in ventral root discharge (ANOVA, $p<0.001 ; n=5-7)$.

Increasing the bath concentration of OXT produced a signif- 

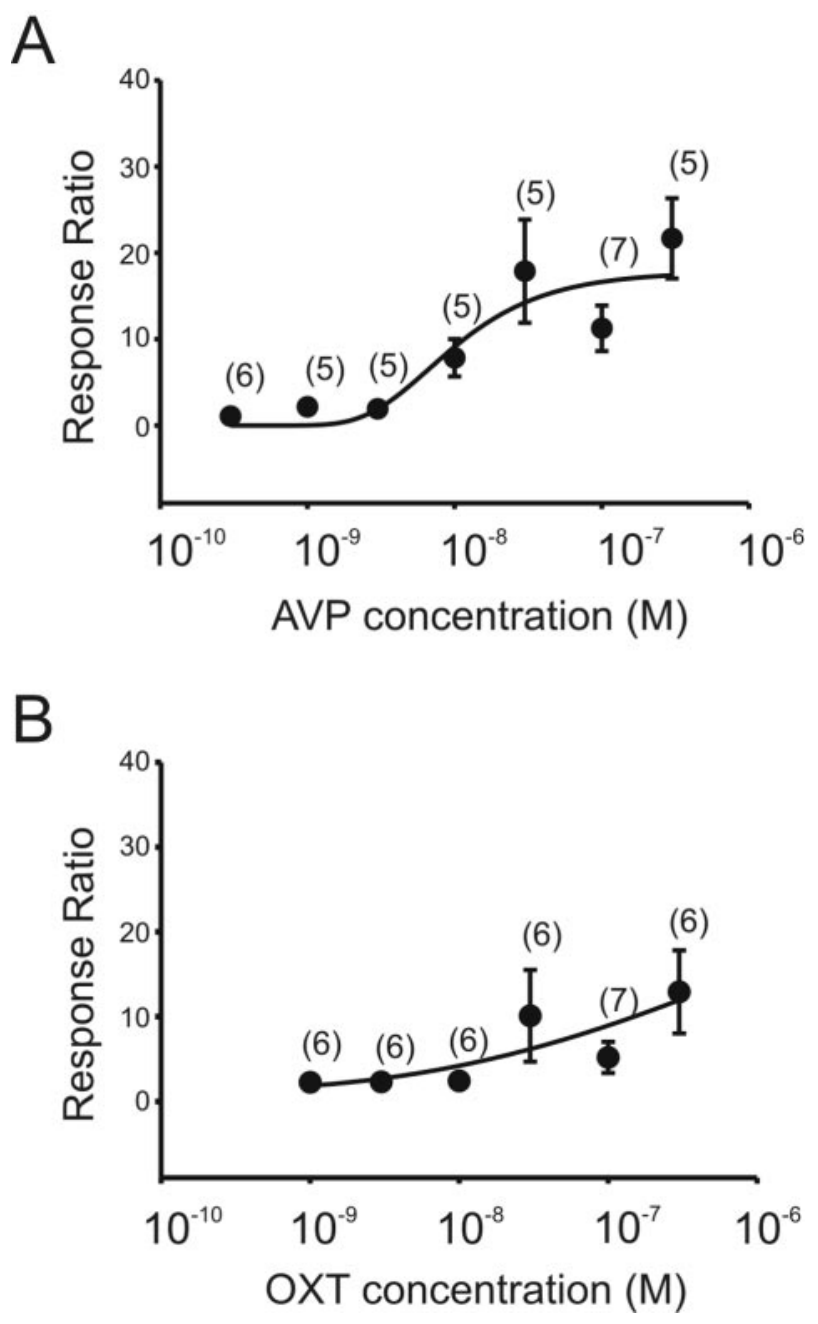

Figure 3. Dose-response curves for bath-applied AVP and OXT. $A$, Dose-response curve for AVP recorded from the $\mathrm{L} 2$ ventral root (concentration range, $0.3-300 \mathrm{~nm}$ ). $B$, Dose-response curve for OXT recorded from the $L 2$ ventral root (concentration range, 1-300 nм). Response ratios for $A$ and $B$ were calculated as a ratio of integrated response activity to integrated baseline activity, each integrated over $5 \mathrm{~min}$. The number of preparations used to calculate the mean is shown in parentheses; the error bars indicate SE. Fifth-order polynomial curves were fit to the data.

icant increase in the L2 ventral root bursting across concentrations (ANOVA, $p<0.05 ; n=5-7$ ) although the post hoc differences between individual groups were not significant; however, a significant post hoc increase was observed in the L5 ventral root response ratios ( $\geq 100 \mathrm{nM}$; ANOVA, $p<0.001 ; n=6-8$ ). $\mathrm{EC}_{50}$ values for AVP and OXT were similar for the L2 and L5 ventral roots (AVP, 13 and $79 \mathrm{~nm}$ from L2 and L5, respectively; OXT, 50 and $35 \mathrm{~nm}$ from L2 and L5, respectively).

\section{Antagonist experiments}

In the next series of experiments we tested whether the AVP and OXT were binding to $\mathrm{V}_{1 \mathrm{a}}$ and OXT receptors, respectively, by testing their specific antagonists SR 49059 and $\left[\mathrm{d}\left(\mathrm{CH}_{2}\right)_{5}{ }^{1}\right.$, Tyr $(\mathrm{Me})^{2}, \mathrm{Thr}^{4}, \mathrm{Orn}^{8}$, des-Gly- $\left.\mathrm{NH}_{2}{ }^{9}\right]$-vasotocin. The antagonists had no effect on baseline activity for AVP ( $\mathrm{V}_{1 \mathrm{a}}$ receptor antagonist: L2, $p=0.2$, paired $t$ test; L5, $p=0.7$, paired $t$ test; $n=25$ ) and OXT (OXT receptor antagonist: L2, $p=0.3$, Wilcoxon Signed Rank test; L5, $p=0.07$, paired $t$ test; $n=10$ ), suggesting that the receptors have no intrinsic effect on bursting and that endogenous ligands were not affecting baseline spontaneous ac-
$\mathrm{Ai}$

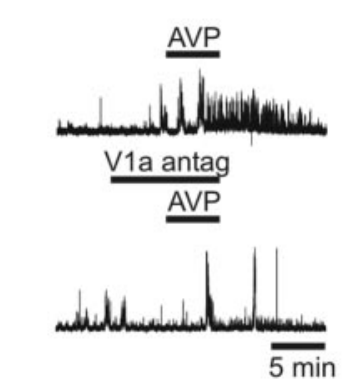

$\mathrm{Bi}$

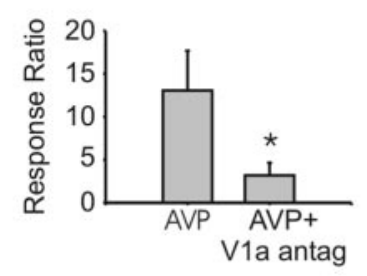

Aii

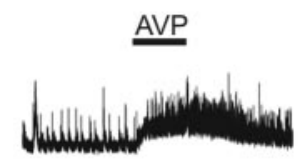

Bii
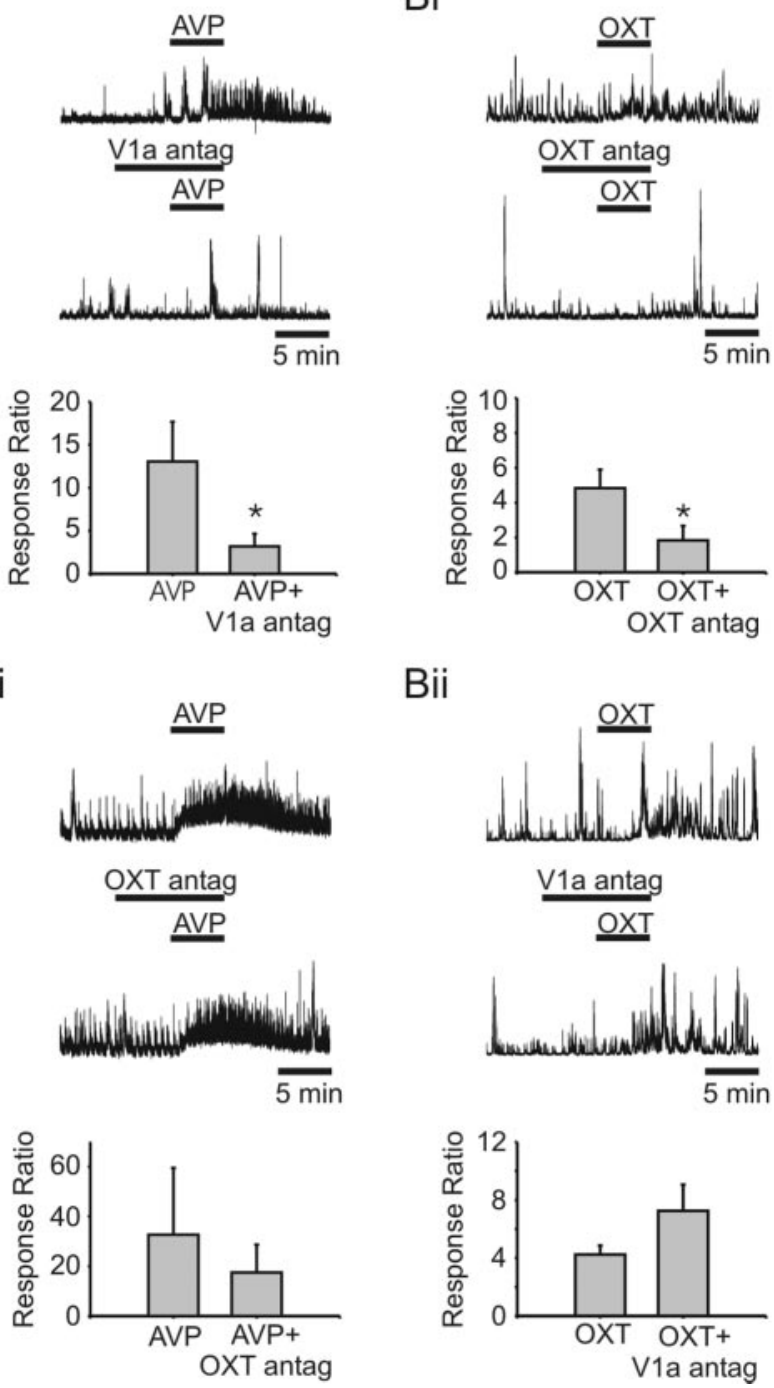

Figure 4. AVP and OXT bind to the $\mathrm{V}_{1 \mathrm{a}}$ and OXT receptors, respectively. Ai, Effects of the bath application of $30 \mathrm{~nm} \mathrm{AVP}$ (black bar; top trace) alone on the L2 ventral root neurogram and in the presence of $300 \mathrm{~nm} \mathrm{~V}_{1 \mathrm{a}}$ receptor antagonist (SR 49059; bottom trace). Bar graph shows that the response ratio amplitude is reduced significantly in the presence of $\mathrm{V}_{1 \mathrm{a}}$ antagonist $(n=12$; $p<$ 0.05). Aii, Effect of the bath application of $30 \mathrm{~nm}$ AVP alone (top trace) on the bursting activity and in the presence of $300 \mathrm{~nm}$ OXT receptor antagonist $\left[\mathrm{d}\left(\mathrm{CH}_{2}\right)_{5}{ }_{5}{ }^{1}, \mathrm{Tyr}(\mathrm{Me})^{2}, \mathrm{Thr}^{4}, \mathrm{Orn}^{8}\right.$, desGly- $\left.\mathrm{NH}_{2}{ }^{9}\right]$-vasotocin (bottom trace); bar graph illustrates the mean response ratio data $(n=4$; $p=0.4$ ). $B i$, Top trace shows the effect of the addition of $30 \mathrm{~nm} 0 \mathrm{XT}$ alone and in the presence of $300 \mathrm{~nm}$ of the OXT receptor antagonist (bottom trace); bar graph illustrates the mean response ratio data ( $n=6 ; p<0.05$ ). Bii, Top trace shows the bursting activity after the bath application of $30 \mathrm{~nm}$ OXT alone and in the presence of $300 \mathrm{~nm}$ of the $V_{1 \mathrm{a}}$ antagonist (bottom trace); bar graph illustrates the mean response ratio data $(n=10 ; p=0.115)$. Error bars indicate SE. All neurogram data are recorded from the $\mathrm{L} 2$ ventral root. Asterisks indicate statistical significance.

tivity. Figure $4 A i$ shows that the ventral root bursting responses evoked after the bath application of AVP were decreased significantly in the presence of the $\mathrm{V}_{1 \mathrm{a}}$ receptor antagonist $(\mathrm{L} 2, p<0.05$; L5, $p<0.005 ; n=12$ ). Although these data suggest that most of the response is being generated by AVP binding to the $\mathrm{V}_{1 \mathrm{a}}$ receptor, it does not rule out the possibility that AVP also binds to OXT receptors, because the two peptides are relatively similar in structure. Blockade of OXT receptors did not reduce the response elicited with $\operatorname{AVP}(\mathrm{L} 2, p>0.1 ; \mathrm{L} 5, p=0.07 ; n=4)$ significantly, suggesting a lack of cross-reactivity with OXT receptors (Fig. 4Aii). However, because the L5 data are slightly above signifi- 


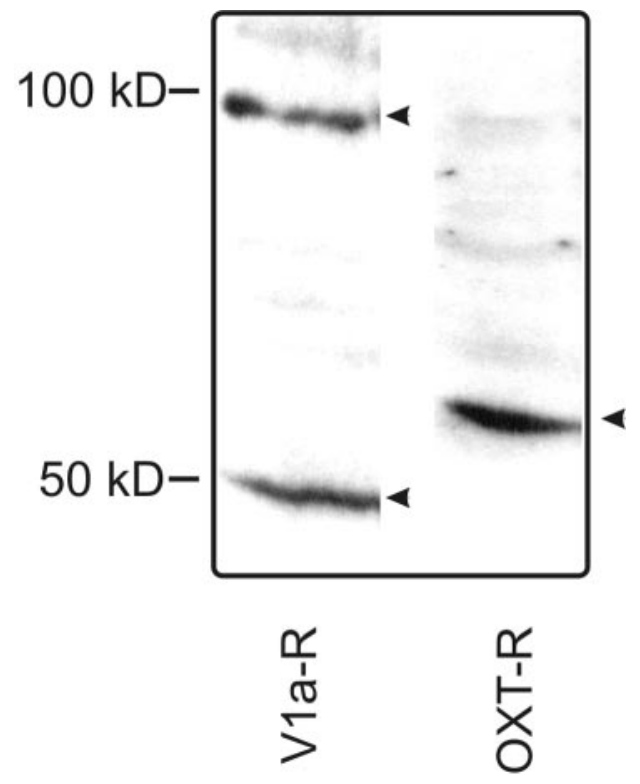

Figure 5. Western blot analysis of lumbar spinal cord tissue from $\mathrm{P3}$ mice results in two bands immunoreactive to $\mathrm{V}_{1 \mathrm{a}}$ receptor antibody $\left(\mathrm{V}_{1 \mathrm{a}}-\mathrm{R}\right)$ with apparent molecular weights of $\sim 48$ and $\sim 96 \mathrm{kDa}$ (left arrowheads). Immunoblotting with OXT receptor antibody (OXT-R) produced a band with an apparent molecular weight of $\sim 55 \mathrm{kDa}$ (right arrowhead).

cance $(p=0.07)$, we are restricting these conclusions to the L2 data.

The response ratios after the bath application of OXT were decreased significantly in the presence of the OXT receptor antagonist (Fig. 4 Bi; L2, $p<0.01 ; \mathrm{L} 5, p<0.01 ; n=6$ ). We found no significant decreases in the OXT-generated response after the administration of a $\mathrm{V}_{1 \mathrm{a}}$ receptor antagonist, suggesting that at these doses there was no appreciable cross-reactivity of OXT with $\mathrm{V}_{1 \mathrm{a}}$ receptors (Fig. 4 Bii; $\mathrm{L} 2, p>0.1 ; \mathrm{L} 5, p>0.1 ; n=10$ ). Collectively, these data argue that both AVP and OXT are producing their effects by binding predominantly to $\mathrm{V}_{1 \mathrm{a}}$ and OXT receptors, respectively.

\section{Expression of $\mathrm{V}_{1 \mathrm{a}}$ and OXT receptors}

As shown in Figure 5, specific immunoreactive bands for both $\mathrm{V}_{1 \mathrm{a}}$ and OXT receptors are present in protein extracts of the lumbar spinal cord of the P3 mouse. Two $\mathrm{V}_{1 \mathrm{a}}$ bands were observed, one of $\sim 48 \mathrm{kDa}$ and a fainter band of $\sim 96 \mathrm{kDa}$. The additional band at $96 \mathrm{kDa}$ may be attributable to dimerization of the receptor. An OXT receptor-specific band (OXT-R) was observed with a molecular weight of $\sim 55 \mathrm{kDa}$ (Fig. 5). Collectively, these data demonstrate that $\mathrm{V}_{1 \mathrm{a}}$ and OXT receptors are expressed in the neonatal mouse lumbar spinal cord.

\section{Effects of AVP and OXT on motor rhythms}

One of the goals of this study was to examine whether AVP or OXT could activate spinal cord networks that generate rhythmic activity. In seven of 33 preparations a transient rhythmic bursting pattern was evoked after the bath application of AVP (10-30 nM). In these seven preparations rhythmic bursting was present in L2 ventral root neurograms (mean cycle period, $1.44 \pm 0.12 \mathrm{sec}$ ). In two of these seven cases AVP application led to the appearance of alternating bursting patterns in the L2 and L5 ventral root neurograms (Fig. 6; cycle periods for L2 and L5 were $1.34 \pm 0.23$ and $1.35 \pm 0.19 \mathrm{sec}$ ). The minimum cross-correlation coefficient was $-0.25 \pm 0.06$, which occurred at 1 lag $(0.05 \mathrm{sec})$ past the zero lag point. The L 5 burst was phase-delayed by $0.47 \pm 0.05$ with re-
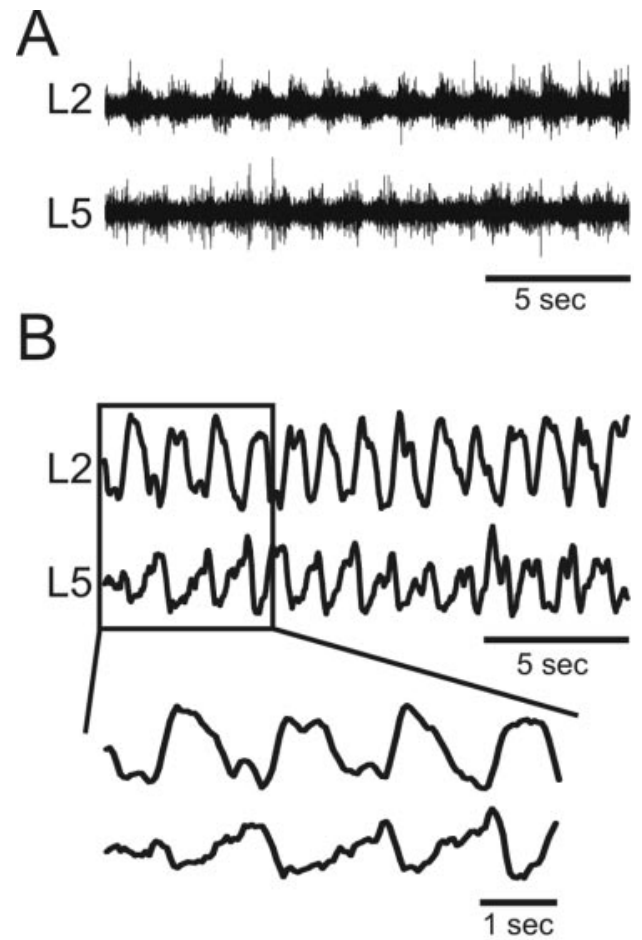

$\mathrm{Ci}$

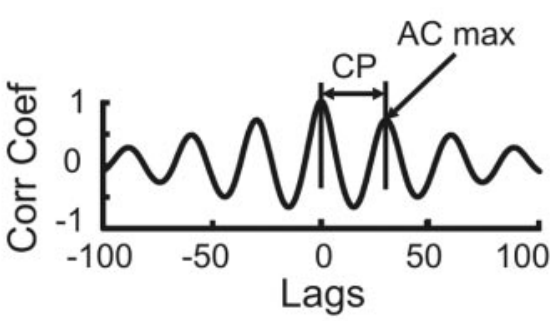

Cii

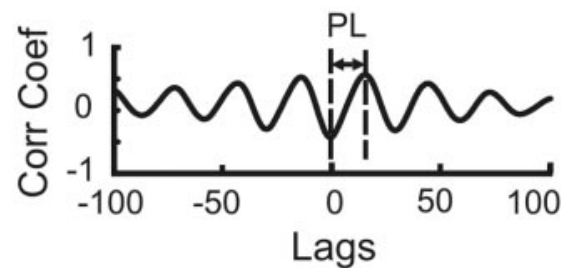

Ciii

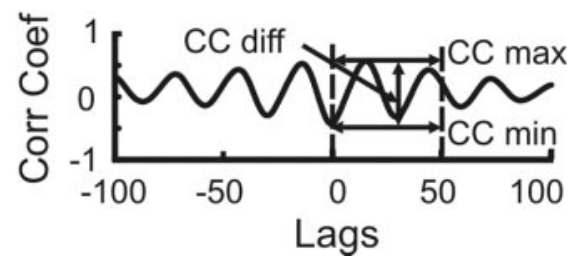

Figure 6. The bath application of AVP can elicit bouts of rhythmic bursting. A, Alternating pattern of rhythmic bursting recorded from the ipsilateral $L 2$ and $L 5$ ventral roots after the bath application of $30 \mathrm{~nm}$ AVP. B, Rectified and smoothed data from A. Bottom traces show expanded portion of the trace indicated by the box. $(i$, Autocorrelogram (AC) from the data in $A$. The cycle period (CP) was calculated as illustrated; $A C$ max provides a measure of the stability of the rhythm indicated by the correlation coefficients (corr coef). Cii, Ciii, Cross-correlograms of data in $A$. Cii, PL is the phase lag in bursting between the two roots. Ciii, Taking the maximum point, cross-correlation maximum (CC max), across 50 lags and subtracting it from the minimum point, cross-correlation minimum ( $(\mathrm{C} \mathrm{min),} \mathrm{produces} \mathrm{the} \mathrm{cross-correlation} \mathrm{difference} \mathrm{(CC} \mathrm{diff)}$ that is a measure of the stability of the alternating rhythm. See Results for details. 
A

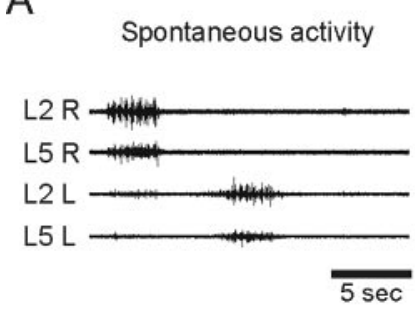

B

$0.5 \mu \mathrm{M} 5-\mathrm{HT}_{2}$ agonist

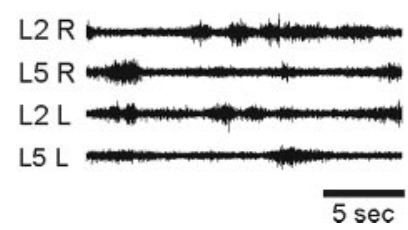

C

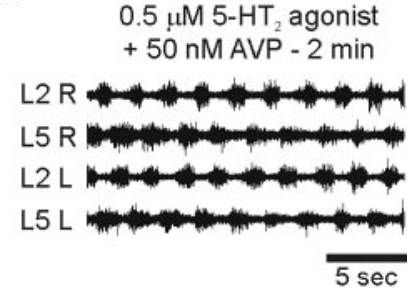

D

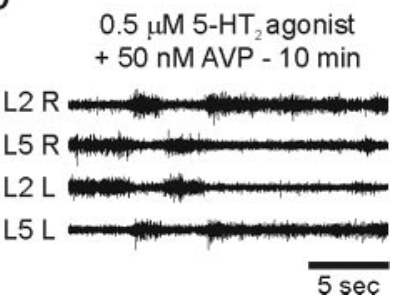

0 lag point (Fig. 8 Aiii). The L2 L and R bursts were phase-delayed by $0.52 \pm 0.01$. The CC min value between the $\mathrm{L} 2 \mathrm{~L}$ and the L $5 \mathrm{~L}$ was $-0.69 \pm 0.05$, occurring 1 lag $(0.05 \mathrm{sec})$ past the 0 lag point (Fig. 8 Biii). The L5 L and L2 L bursts were phase-delayed by $0.50 \pm 0.01$. Phase values close to 0.5 between bursts from ipsilateral L2 and L5 and segmental L2 ventral roots are a signature of locomotor-like activity (Whelan et al., 2000). The autocorrelation values that reflect the stability of the rhythm were $0.51 \pm 0.1$, $0.45 \pm 0.13$, and $0.54 \pm 0.06$ for the L2 R, L2 L, and L5 L neurograms, respectively. The cycle periods for the L2 L, L2 R, and L5 L bursts were $1.5 \pm 0.2,1.6 \pm 0.2$, and $1.6 \pm 0.2 \mathrm{sec}$, respectively (Fig. 8 Aiii,Biii; $n=4$ ).

OXT also was tested in combination with subthreshold concentrations of $\alpha$-m-5-HT $(1 \mu \mathrm{M})$ that did not generate a stable locomotor-like rhythm (Fig. 9B). Application of $100 \mathrm{~nm}$ OXT elicited episodic bouts of locomotor-like rhythmicity, which peaked $2 \mathrm{~min}$ after application of OXT, in three of five preparations (Fig. 9C) and degraded rapidly over the course of $10 \mathrm{~min}$ (Fig. 9D). The response differs from that seen in experiments with AVP and $\alpha-\mathrm{m}-5-\mathrm{HT}$, because episodic bouts of rhythmicity were produced, and the coupling between the segmental and ipsilateral rhythms was not as strong. The stability of rhythms was quantified in the same way as the AVP and $\alpha-\mathrm{m}-5-\mathrm{HT}$ data, using time series analysis for the $5 \mathrm{~min}$ before and $10 \mathrm{~min}$ after OXT application. The stability of the coupled alternating rhythm plotted as CC diff (see above) was greatest 2 min after applying OXT (Fig. 10 Ai,Bi). Again the properties of the rhythm were examined at this point for each preparation (Fig. 10Aii,Bii). The CC min value for L2 R and L2 L was $-0.38 \pm 0.07$, which occurred 2.3 lags $(0.12 \mathrm{sec})$ past the $0 \mathrm{lag}$ point (Fig. $10 \mathrm{Aiii})$, and the bursts were phase-delayed by $0.56 \pm 0.02$. The CC min value between L2 L and L5 L was $0.06 \pm 0.10$, occurring 1.3 lags $(0.07 \mathrm{sec})$ after the 0 lag point, and the bursts were phase-delayed by $0.44 \pm 0.03$. The autocorrelation values were $0.54 \pm 0.05,0.55 \pm 0.08$ and $0.73 \pm$ 0.02 for the L2 R, L2 L, and L5 L, respectively. The cycle periods for the L2 L, L2 R, and L5L bursts were $1.7 \pm 0.3,1.7 \pm 0.3$, and $1.5 \pm 0.2 \mathrm{sec}$, respectively (Fig. 10 Aiii,Biii).

\section{Discussion}

In the neonatal rat it has been reported that AVP and OXT can depolarize motoneurons, interneurons, and preganglionic neurons in the spinal cord, leading to increased spike activity (Suzue et al., 1981; Kolaj and Renaud, 1998; Oz et al., 2001; Liu et al., 2003). A key question is whether widespread activation of these spinal neurons can produce functional motor effects. Using an en bloc preparation of the isolated mouse spinal cord, we show that the bath application of AVP produces widespread multisegmental activation of spinal neurons that can activate networks capable of producing rhythmic activity. Furthermore, when AVP or OXT and $\alpha$-m-5-HT are bath-applied, a combinatorial increase in the expression of rhythmic behavior occurs. Our results demonstrate that AVP and OXT can facilitate patterned motor behavior either independently or in cooperation with other neuromodulators.

\section{OXT and AVP can activate somatic motoneurons}

Several lines of evidence suggest that the majority of the peptideinduced bursting behavior recorded from the lumbar ventral roots is a product of somatic motoneuronal spike activity. First, the bath application of OXT and especially AVP led to an increase in EMG discharge from the TA, TS, and quadriceps. Similarly, increases in the bursting discharge recorded from the common

peroneal nerve (a motor nerve) occurred after the administration
(Fig 8 Aii Bii). The CC min value, the minimum correlation coefficient, was $-0.66 \pm 0.06$, occurring 1.75 lags $(0.09 \mathrm{sec})$ past the 

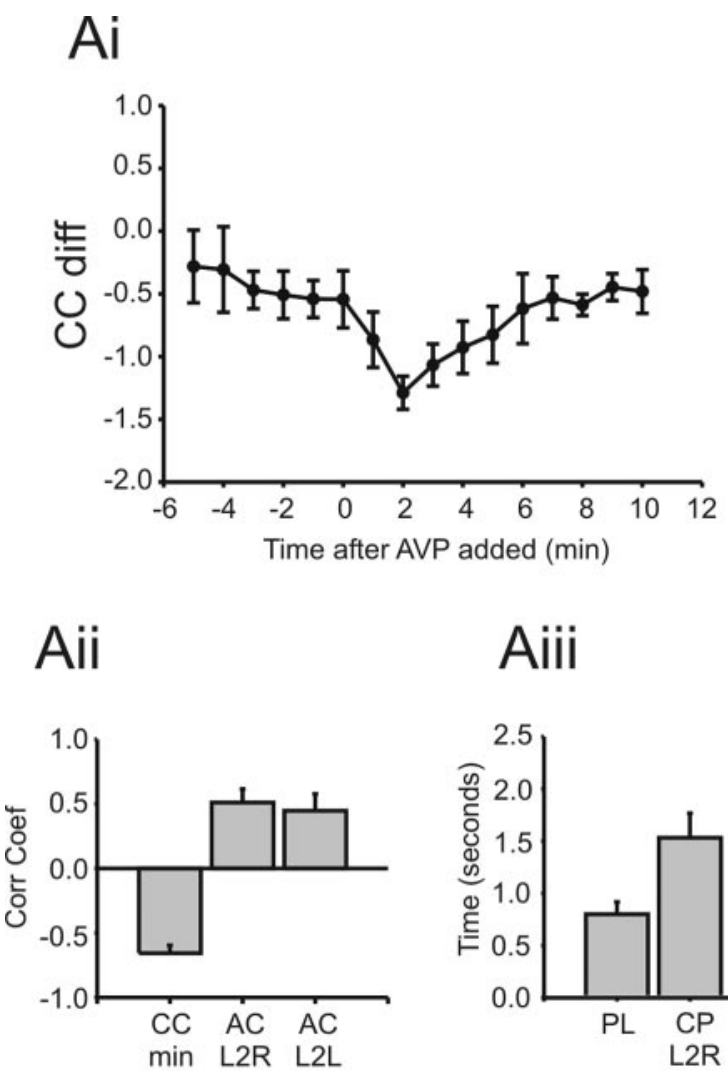

\section{Aiii}

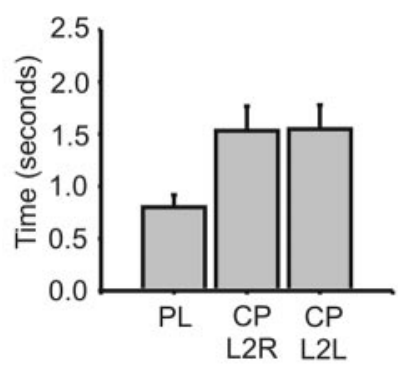

$\mathrm{Bi}$

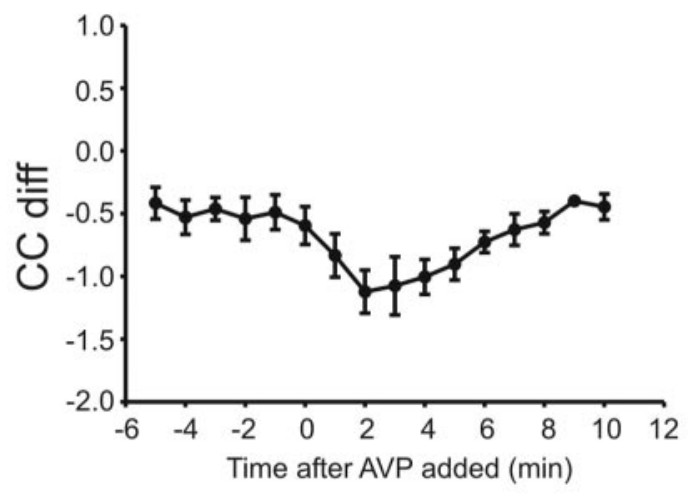

Bii
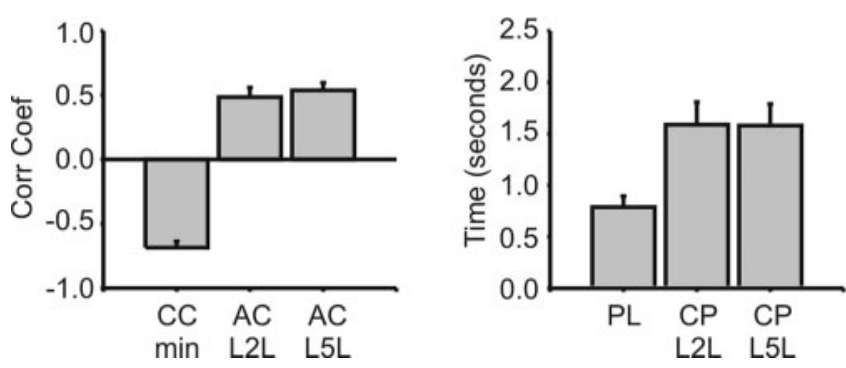

Figure 8. Summary data quantifying the transient rhythmogenic effect of bath-applied AVP with $\alpha-\mathrm{m}-5-\mathrm{HT}$ ( $n=4$ for each). A, Data from segmental L2 ventral roots. Ai, Plot of the CC diff (see Fig. 6 and Results) calculated in serial 60 sec intervals from the segmental L2 ventral root data. Note the decrease in the correlation coefficient after the addition of AVP to the bath, followed by an increase. This reflects the establishment of an alternating segmental pattern of bursting, followed by its decay. Aii, Bar graph quantifies the stability of the alternation and
A

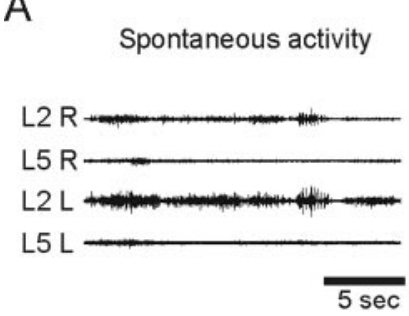

C

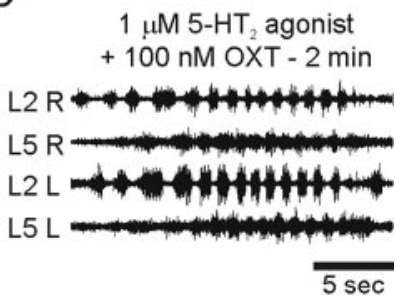

B $1 \mu \mathrm{M} 5-\mathrm{HT}_{2}$ agonist

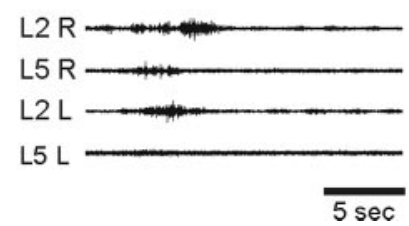

$\mathrm{D}$

$1 \mu \mathrm{M} 5-\mathrm{HT}_{2}$ agonist $+100 \mathrm{nM}$ OXT - $10 \mathrm{~min}$

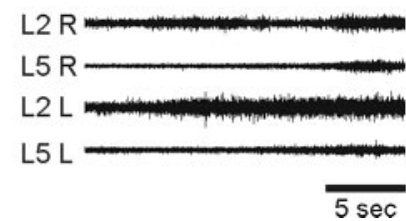

Figure 9. OXT can interact with a 5- $\mathrm{HT}_{2}$ receptor agonist to evoke bouts of alternating activity. $A$, Spontaneous activity recorded from right and left $\mathrm{L} 2$ and $\mathrm{L} 5$ ventral roots. $B$, Bath application of $5-\mathrm{HT}_{2}$ agonist to the bath ( $1 \mu \mathrm{m} \alpha-\mathrm{m}-5-\mathrm{HT}$ ) for a period of $30 \mathrm{~min}$ produced some increase in discharge, but no bouts of rhythmic activity. C, Serial application of OXT (100 nM) to the bath resulted in frequent periods of rhythmic activity. $D$, The periods of rhythmic activity decreased in regularity and length over time, there being no coordinated rhythmic pattern 10 min after OXT application. All data were obtained from the same preparation.

of both peptides. Second, rhythmic alternating bursts of discharge were observed after the administration of AVP, a phenomenon associated with activation of muscles (Whelan et al., 2000). Finally, in neonatal rat slices the bath application of AVP increased the frequency of spikes recorded from identified motoneurons in the ventral horn (Oz et al., 2001; Liu et al., 2003). Collectively, these data suggest that $\alpha$-motoneurons are being activated by OXT and AVP acting on OXT and $\mathrm{V}_{1 \mathrm{a}}$ receptors, respectively.

Our data do not exclude the possibility that preganglionic neurons, which also project to the ventral root, contribute to the population bursting activity. Indeed, on the basis of data from neonatal rat slice preparations, we consider this a likely possibility (Ma and Dun, 1985; Kolaj and Renaud, 1998). Nevertheless, although the data on neonatal mice are limited, retrograde labeling of L2 ventral roots suggests that the majority of projections is from somatic motoneurons (Bonnot et al., 2002). This also is reflected by the widespread activation of muscles with different functions [quadriceps (knee extensor), TA (ankle flexor), TS (ankle extensor)] by bath application of either OXT or AVP.

\section{Activation of motor networks}

Several neuromodulators and/or neurotransmitter agonists induce or modulate rhythmic activity in the isolated spinal cord preparation of the neonatal rodent. These include 5-HT, dopa-

$\leftarrow$

rhythmicity between segmental $\mathrm{L} 2$ roots at the minimum values of $C \mathrm{C}$ diff for each preparation (i.e., peak rhythmicity). CC min is the mean correlation coefficient at the first trough of the cross-correlogram. AC refers to the autocorrelation coefficients recorded at the first peak after the zero lag point for both roots. Aiii, Bar graph; CP L2 R and CP L2 L refer to the mean cycle period time of the right and left ventral roots, respectively. $\mathrm{PL}$ is the mean phase lag (expressed in sec) between the left and right $L 2$ bursting patterns. $B$, Data recorded from the left $L 2$ and $L 5$ ventral roots. $B i$, The stability of the alternating $L 2$ and $L 5$ rhythm peaks at the same time as the segmental L2 data. Bii, Bar graph summarizes the stability of the alternation and rhythmicity. Biii, Bar graph displays mean cycle period and phase delay data for the L2 and L5 ventral roots. Error bars indicate SE. 

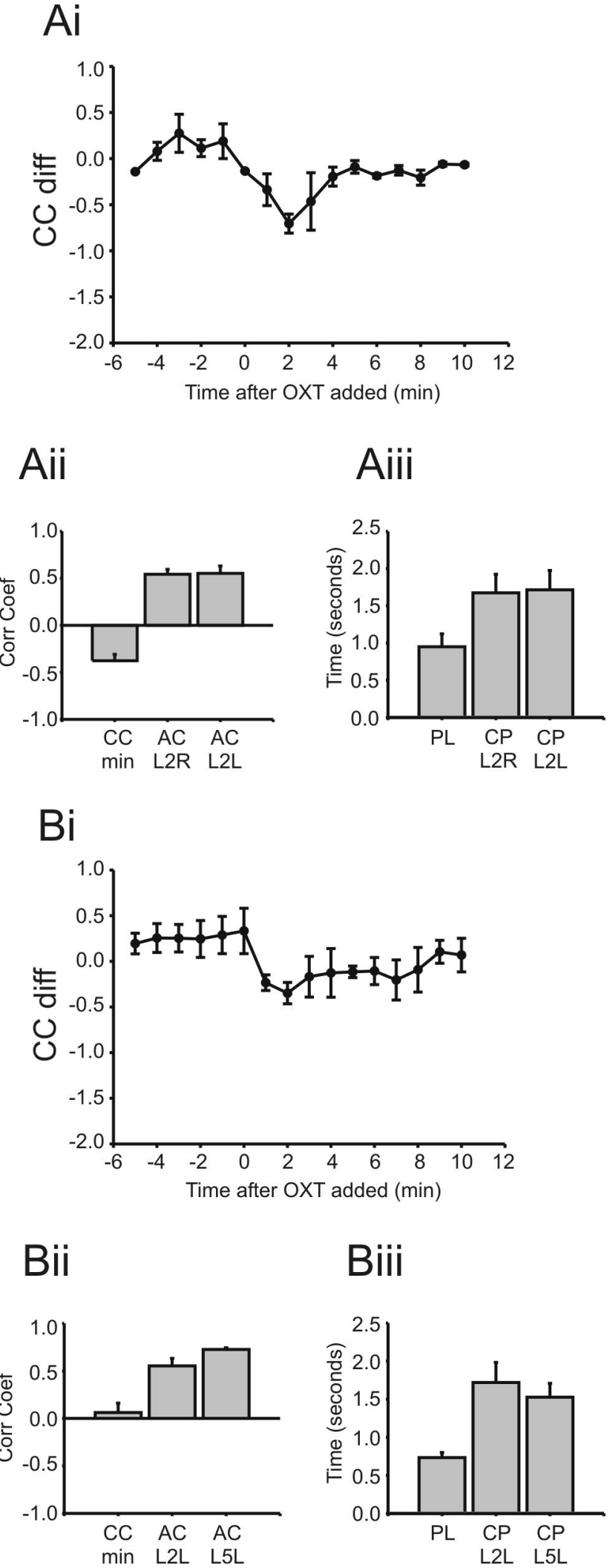

\section{$\mathrm{Bi}$}

$\min \mathrm{L} 2 \mathrm{~L} \quad \mathrm{~L} 5 \mathrm{~L}$

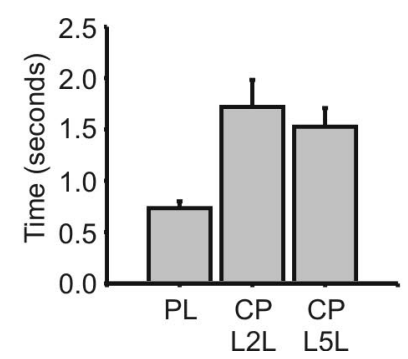

Figure 10. Summary data quantifying the transient rhythms generated in the presence of $\alpha-\mathrm{m}-5-\mathrm{HT}$ and OXT $(n=3)$. A, Data from segmental L2 ventral roots. Ai, Plot of the CC diff, calculated in serial 60 sec intervals (as in Fig. 8). Note the decrease in the correlation coefficient after the addition of OXT, reflecting the establishment of a rhythmic pattern. Aii, Bar graph quantifies the stability of the alternation and rhythmicity at the minimum values of CC diff (i.e., peak rhythmicity; see Fig. 8 for details). Aiii, Bar graph; (P L2 R and L2 L refers to the mean cycle period (in sec) of the right and left ventral roots, respectively. PL is the mean phase lag (in sec) mine, NMDA, tachykinins, acetylcholine, and noradrenaline (Cazalets et al., 1992; Barthe and Clarac, 1997; Cowley and Schmidt, 1997; Bracci et al., 1998; Kiehn et al., 1999). Although bath-applied AVP could, on occasion, evoke bouts of locomotorlike rhythmicity, it more often resulted in tonic activity. Conversely, when AVP was bath-applied in combination with a $5-\mathrm{HT}_{2}$ agonist, coordinated locomotor-like bursts were recorded in a majority of preparations. One explanation for the combined effectiveness of the AVP $/ \alpha-\mathrm{m}-5$-HT mixture may be attributable to the putative location for the central pattern generator (CPG) within the ventral portion of the spinal cord (Kjaerulff and Kiehn, 1996; Wilson et al., 2003). Because 5- $\mathrm{HT}_{2 \mathrm{a}}$ receptors appear to be localized within the ventral horn (Pompeiano et al., 1994), 5- $\mathrm{HT}_{2}$ receptor agonists would be expected to activate preferentially the neurons comprising the CPG. In contrast, $\mathrm{V}_{\mathrm{la}}$ receptors are expressed ubiquitously throughout the spinal cord (Tribollet et al., 1991), and bath-applied AVP likely depolarizes a majority of neurons in the spinal cord (Oz et al., 2001). The activity of neurons lying outside the CPG could destabilize the network and may account for the relatively low number of preparations in which the bath application of AVP led to the production of rhythmic activity. On the other hand, neurons within the CPG may be "primed" by the application of subthreshold amounts of 5- $\mathrm{HT}_{2}$ receptor agonists. Serial application of AVP may depolarize a significant population of neurons within the CPG and allow emergent network properties to be expressed. Further experiments that use intracellular recording techniques will be necessary to test these ideas.

In contrast with AVP, the bath application of OXT did not evoke bouts of coordinated activity. However, OXT could interact with $5-\mathrm{HT}_{2}$ receptor agonists to produce locomotor patterns, suggesting that it can cause depolarization of sufficient interneurons comprising the CPG. However, the periods of locomotor activity were episodic and not sustained as with AVP. One possibility is that OXT less effectively depolarizes neuronal elements of the CPG as compared with AVP. Differential effectiveness of the two peptides has been observed in lateral horn cells in which the bath application of OXT produced significantly smaller membrane depolarizations as compared with AVP (Kolaj and Renaud, 1998). Oz et al. (2001) found that, of the motoneurons they tested, few responded to OXT receptor agonist, and Suzue et al. (1981) found that the depolarization elicited by OXT was far more sensitive to TTX than that produced by AVP, suggesting lower expression of OXT receptors on motoneurons. In agreement with Renaud and colleagues (Kolaj and Renaud, 1998; Oz et al., 2001), the bath application of OXT produced smaller increases in burst discharge.

\section{Endogenous source of peptides}

Although our study has provided functional evidence for AVP and OXT receptors in the neonatal mouse spinal cord, we have no knowledge as of yet whether they are activated normally in vivo. Potential sources of endogenous AVP and OXT in the developing mouse spinal cord have yet to be explored, but in the neonatal rat there is evidence of fibers from the PVN reaching the thoracic

$\leftarrow$

between the $L 2 R$ and $L 2 L$ bursting patterns. $B$, Data recorded from the $L 2 L$ and $L 5 L$ ventral roots. $B i$, The stability of the alternating rhythm peaks at the same time as the segmental $L 2$ data. Bii, Bar graph quantifies the stability of the alternation and rhythmicity at the minimum values of CC diff. Biii, Bar graph displays mean cycle period and phase lag data for the L2 and L5 ventral roots. Error bars indicate SE. 
cord before birth and the lumbar cord by P2 (Leong et al., 1984; Kudo et al., 1993; Lakke, 1997), although it is not known whether these contain AVP or OXT. In the adult there are known AVP and OXT projections to autonomic regions within the spinal cord from the PVN and suprachiasmatic nucleus (AVP only) (Buijs, 1978; Nilaver et al., 1980; Sawchenko and Swanson, 1982; Hallbeck and Blomqvist, 1999; Motawei et al., 1999; Puder and Papka, 2001). On the other hand, there are alternative ways in which AVP or OXT may enter the extracellular space of the spinal cord and activate neurons. In neonatal mice the blood-brain barrier is not formed fully, and AVP or OXT in the blood could cross a leaky blood-brain barrier (Vorbrodt et al., 1986) and depolarize neurons. However, it is unclear whether hormonal blood concentrations would be high enough to produce functional effects. Another possibility is that AVP/OXT could be secreted into the neonatal CSF, as has been observed in adult rats (Dogterom et al., 1977).

\section{Overexpression of receptors in the spinal cord: functional role?}

An overexpression of receptors combined with the relatively high-input resistance of developing motoneurons (Vinay et al., 2000) may be partly responsible for the production of spontaneous network activity (see Introduction), thought to play a role in fine-tuning circuits (Katz and Shatz, 1996). Although we have concentrated on the discussion of locomotor-like activity evoked by AVP and OXT, these peptides could participate equally in the generation of spontaneous activity in the neonatal mouse spinal cord (Whelan et al., 2000). Given the widespread effects of AVP and OXT on motor output in the en bloc preparation, it will be important to test whether chronic blockade of $\mathrm{V}_{\text {la }}$ and OXT receptors impairs motor development.

It is worth noting that some neurotransmitters and peptides act as trophic agents during development (Behar et al., 1994). For example, AVP and/or OXT have/has been shown to promote neurite outgrowth from cultured neurons obtained from the ventral spinal cord (Ikeda et al., 1989; Iwasaki et al., 1991) and from cultured neurons obtained from supraoptic nucleus (Chevaleyre et al., 2002). Furthermore, overexpressed receptors can interact with traditional neurotrophic factors to increase the plasticity of spinal circuits. For instance, neurotrophin-3 (NT-3) interacts with AMPA/kainate receptors on motoneurons to increase synaptic strength in neonatal rats but loses the capability to do this when AMPA and NMDA receptor levels decrease (Arvanov et al., 2000). One possibility for this interaction involves NT-3, causing an increased activation of NMDA receptors leading to downstream phosphorylation of AMPA receptors.

\section{Conclusions}

This study illustrates for the first time the dramatic effects of neurohypophysial peptides on motor behavior in en bloc neonatal mouse preparations. AVP can trigger bouts of locomotor-like activity, suggesting that it can directly activate the neurons that are members of spinal motor networks. This is in contrast to the mainly autonomic roles these peptides play in adult animals (Pittman et al., 1982; Riphagen and Pittman, 1985, 1989; Malpas and Coote, 1994; Pandita et al., 1998; Giuliano and Rampin, 2000). Clearly, we need to perform experiments that examine the developmental function of these receptors by using in vivo neonatal animals. Equally important is discovering the endogenous source of these peptides in the neonatal spinal cord.

\section{References}

Arvanov VL, Seebach BS, Mendell LM (2000) NT-3 evokes an LTP-like facilitation of AMPA/kainate receptor-mediated synaptic transmission in the neonatal rat spinal cord. J Neurophysiol 84:752-758.

Barthe JY, Clarac F (1997) Modulation of the spinal network for locomotion by substance P in the neonatal rat. Exp Brain Res 115:485-492.

Behar TN, Schaffner AE, Colton CA, Somogyi R, Olah Z, Lehel C, Barker JL (1994) GABA-induced chemokinesis and NGF-induced chemotaxis of embryonic spinal cord neurons. J Neurosci 14:29-38.

Ben Ari Y (2001) Developing networks play a similar melody. Trends Neurosci 24:353-360.

Bonnot A, Whelan PJ, Mentis GZ, O’Donovan MJ (2002) Spatiotemporal pattern of motoneuron activation in the rostral lumbar and the sacral segments during locomotor-like activity in the neonatal mouse spinal cord. J Neurosci 22:RC203(1-6).

Bracci E, Beato M, Nistri A (1998) Extracellular $\mathrm{K}^{+}$induces locomotor-like patterns in the rat spinal cord in vitro: comparison with NMDA or 5-HT induced activity. J Neurophysiol 79:2643-2652.

Buijs RM (1978) Intra- and extrahypothalamic vasopressin and oxytocin pathways in the rat. Pathways to the limbic system, medulla oblongata, and spinal cord. Cell Tissue Res 192:423-435.

Cazalets JR, Sqalli-Houssaini Y, Clarac F (1992) Activation of the central pattern generators for locomotion by serotonin and excitatory amino acids in neonatal rat. J Physiol (Lond) 455:187-204.

Chevaleyre V, Moos FC, Desarmenien MG (2002) Interplay between presynaptic and postsynaptic activities is required for dendritic plasticity and synaptogenesis in the supraoptic nucleus. J Neurosci 22:265-273.

Clarac F, Vinay L, Cazalets JR, Fady JC, Jamon M (1998) Role of gravity in the development of posture and locomotion in the neonatal rat. Brain Res Brain Res Rev 28:35-43.

Clerget-Froidevaux MS, Pittman QJ (2003) AVP V1a-R expression in the rat hypothalamus around parturition: relevance to antipyresis at term. Exp Neurol 183:338-345.

Cowley KC, Schmidt BJ (1997) Regional distribution of the locomotor pattern-generating network in the neonatal rat spinal cord. J Neurophysiol 77:247-259.

Desaulles E, Reiter MK, Feltz P (1995) Electrophysiological evidence for oxytocin receptors on sympathetic preganglionic neurones-an in vitro study on the neonatal rat. Brain Res 699:139-142.

Dogterom J, Van Wimersma Greidanus TB, Swabb DF (1977) Evidence for the release of vasopressin and oxytocin into cerebrospinal fluid: measurements in plasma and CSF of intact and hypophysectomized rats. Neuroendocrinology 24:108-118.

Feller MB (1999) Spontaneous correlated activity in developing neural circuits. Neuron 22:653-656.

Giuliano F, Rampin O (2000) Central noradrenergic control of penile erection. Int J Impot Res 12[Suppl 1]:S13-S19.

Hallbeck M, Blomqvist A (1999) Spinal cord-projecting vasopressinergic neurons in the rat paraventricular hypothalamus. J Comp Neurol 411:201-211.

Hallbeck M, Larhammar D, Blomqvist A (2001) Neuropeptide expression in rat paraventricular hypothalamic neurons that project to the spinal cord. J Comp Neurol 433:222-238.

Hawthorn J, Ang VT, Jenkins JS (1980) Localization of vasopressin in the rat brain. Brain Res 197:75-81.

Hurbin A, Orcel H, Alonso G, Moos F, Rabie A (2002) The vasopressin receptors colocalize with vasopressin in the magnocellular neurons of the rat supraoptic nucleus and are modulated by water balance. Endocrinology 143:456-466.

Ikeda K, Kinoshita M, Iwasaki Y, Shiojima T, Takamiya K (1989) Neurotrophic effect of angiotensin II, vasopressin, and oxytocin on the ventral spinal cord of rat embryo. Int J Neurosci 48:19-23.

Inglis FM, Crockett R, Korada S, Abraham WC, Hollmann M, Kalb RG (2002) The AMPA receptor subunit GluR1 regulates dendritic architecture of motor neurons. J Neurosci 22:8042-8051.

Iwasaki Y, Kinoshita M, Ikeda K, Shiojima T, Kurihara T, Appel SH (1991) Trophic effect of angiotensin II, vasopressin, and other peptides on the cultured ventral spinal cord of rat embryo. J Neurol Sci 103:151-155.

Jakowec MW, Fox AJ, Martin LJ, Kalb RG (1995) Quantitative and qualitative changes in AMPA receptor expression during spinal cord development. Neuroscience 67:893-907.

Jiang Z, Carlin KP, Brownstone RM (1999) An in vitro functionally mature 
mouse spinal cord preparation for the study of spinal motor networks. Brain Res 816:493-499.

Jo YH, Stoeckel ME, Freund-Mercier MJ, Schlichter R (1998) Oxytocin modulates glutamatergic synaptic transmission between cultured neonatal spinal cord dorsal horn neurons. J Neurosci 18:2377-2386.

Kalb RG, Lidow MS, Halsted MJ, Hockfield S (1992) N-methyl-D-aspartate receptors are transiently expressed in the developing spinal cord ventral horn. Proc Natl Acad Sci USA 89:8502-8506.

Katz LC, Shatz CJ (1996) Synaptic activity and the construction of cortical circuits. Science 274:1133-1138.

Kiehn O, Sillar KT, Kjaerulff O, McDearmid JR (1999) Effects of noradrenaline on locomotor rhythm-generating networks in the isolated neonatal rat spinal cord. J Neurophysiol 82:741-746.

Kjaerulff O, Kiehn O (1996) Distribution of networks generating and coordinating locomotor activity in the neonatal rat spinal cord in vitro: a lesion study. J Neurosci 16:5777-5794.

Kolaj M, Renaud LP (1998) Vasopressin-induced currents in rat neonatal spinal lateral horn neurons are G-protein mediated and involve two conductances. J Neurophysiol 80:1900-1910.

Kudo N, Furukawa F, Okado N (1993) Development of descending fibers to the rat embryonic spinal cord. Neurosci Res 16:131-141.

Lakke EA (1997) The projections to the spinal cord of the rat during development: a timetable of descent [review]. Adv Anat Embryol Cell Biol 135:1-143.

Leong SK, Shieh JY, Wong WC (1984) Localizing spinal cord-projecting neurons in adult albino rats. J Comp Neurol 228:1-17.

Liu X, Tribollet E, Ogier R, Barberis C, Raggenbass M (2003) Presence of functional vasopressin receptors in spinal ventral horn neurons of young rats: a morphological and electrophysiological study. Eur J Neurosci 17:1833-1846.

Ma RC, Dun NJ (1985) Vasopressin depolarizes lateral horn cells of the neonatal rat spinal cord in vitro. Brain Res 348:36-43.

Ma W, Behar T, Chang L, Barker JL (1994) Transient increase in expression of GAD65 and GAD67 mRNAs during postnatal development of rat spinal cord. J Comp Neurol 346:151-160.

Malpas SC, Coote JH (1994) Role of vasopressin in sympathetic response to paraventricular nucleus stimulation in anesthetized rats. Am J Physiol 266:R228-R236.

Motawei K, Pyner S, Ranson RN, Kamel M, Coote JH (1999) Terminals of paraventricular spinal neurones are closely associated with adrenal medullary sympathetic preganglionic neurones: immunocytochemical evidence for vasopressin as a possible neurotransmitter in this pathway. Exp Brain Res 126:68-76.

Mukaddam-Daher S, Jankowski M, Wang D, Menaouar A, Gutkowska J (2002) Regulation of cardiac oxytocin system and natriuretic peptide during rat gestation and postpartum. J Endocrinol 175:211-216.

Nilaver G, Zimmerman EA, Wilkins J, Michaels J, Hoffman D, Silverman AJ (1980) Magnocellular hypothalamic projections to the lower brain stem and spinal cord of the rat. Immunocytochemical evidence for predominance of the oxytocin-neurophysin system compared to the vasopressinneurophysin system. Neuroendocrinology 30:150-158.

O’Donovan MJ, Wenner P, Chub N, Tabak J, Rinzel J (1998) Mechanisms of spontaneous activity in the developing spinal cord and their relevance to locomotion. Ann NY Acad Sci 860:130-141.

Oz M, Kolaj M, Renaud LP (2001) Electrophysiological evidence for vasopressin $V_{1}$ receptors on neonatal motoneurons, premotor and other ventral horn neurons. J Neurophysiol 86:1202-1210.

Pandita RK, Nylen A, Andersson KE (1998) Oxytocin-induced stimulation and inhibition of bladder activity in normal, conscious rats-influence of nitric oxide synthase inhibition. Neuroscience 85:1113-1119.
Pearson SA, Madriaga MA, Whelan PJ, Pittman QJ (2002) Effects of vasopressin and oxytocin on motoneuron bursting in the in vitro neonatal mouse spinal cord. Soc Neurosci Abstr 32:167.13.

Pittman QJ, Lawrence D, McLean L (1982) Central effects of arginine vasopressin on blood pressure in rats. Endocrinology 110:1058-1060.

Pompeiano M, Palacios JM, Mengod G (1994) Distribution of the serotonin 5-HT2 receptor family mRNAs: comparison between 5-HT2A and 5-HT2C receptors. Brain Res Mol Brain Res 23:163-178.

Puder BA, Papka RE (2001) Hypothalamic paraventricular axons projecting to the female rat lumbosacral spinal cord contain oxytocin immunoreactivity. J Neurosci Res 64:53-60.

Reiter MK, Kremarik P, Freund-Mercier MJ, Stoeckel ME, Desaulles E, Feltz $P$ (1994) Localization of oxytocin binding sites in the thoracic and upper lumbar spinal cord of the adult and postnatal rat: a histoautoradiographic study. Eur J Neurosci 6:98-104.

Riphagen CL, Pittman QJ (1985) Vasopressin influences renal function via a spinal action. Brain Res 336:346-349.

Riphagen CL, Pittman QJ (1989) Spinal arginine vasopressin elevates renal nerve activity in the rat. J Neuroendocrinol 1:339-344.

Sawchenko PE, Swanson LW (1982) Immunohistochemical identification of neurons in the paraventricular nucleus of the hypothalamus that project to the medulla or to the spinal cord in the rat. J Comp Neurol 205:260-272.

Seebach BS, Ziskind-Conhaim L (1994) Formation of transient inappropriate sensorimotor synapses in developing rat spinal cords. J Neurosci 14:4520-4528.

Sermasi E, Coote JH (1994) Oxytocin acts at $\mathrm{V}_{1}$ receptors to excite sympathetic preganglionic neurones in neonate rat spinal cord in vitro. Brain Res 647:323-332.

Stegenga SL, Kalb RG (2001) Developmental regulation of N-methyl-Daspartate- and kainate-type glutamate receptor expression in the rat spinal cord. Neuroscience 105:499-507.

Suzue T, Yanaihara N, Otsuka M (1981) Actions of vasopressin, gastrinreleasing peptide, and other peptides on neurons on newborn rat spinal cord in vitro. Neurosci Lett 26:137-142.

Swanson LW, McKellar S (1979) The distribution of oxytocin- and neurophysin-stained fibers in the spinal cord of the rat and monkey. J Comp Neurol 188:87-106.

Tribollet E, Charpak S, Schmidt A, Dubois-Dauphin M, Dreifuss JJ (1989) Appearance and transient expression of oxytocin receptors in fetal, infant, and peripubertal rat brain studied by autoradiography and electrophysiology. J Neurosci 9:1764-1773.

Tribollet E, Goumaz M, Raggenbass M, Dubois-Dauphin M, Dreifuss JJ (1991) Early appearance and transient expression of vasopressin receptors in the brain of rat fetus and infant. An autoradiographical and electrophysiological study. Brain Res Dev Brain Res 58:13-24.

Vinay L, Brocard F, Pflieger JF, Simeoni-Alias J, Clarac F (2000) Perinatal development of lumbar motoneurons and their inputs in the rat. Brain Res Bull 53:635-647.

Vorbrodt AW, Lossinsky AS, Wisniewski HM (1986) Localization of alkaline phosphatase activity in endothelia of developing and mature mouse blood-brain barrier. Dev Neurosci 8:1-13.

Whelan PJ, Bonnot A, O'Donovan MJ (2000) Properties of rhythmic activity generated by the isolated spinal cord of the neonatal mouse. J Neurophysiol 84:2821-2833.

Wilson RJ, Chersa T, Whelan PJ (2003) Tissue $\mathrm{PO}_{2}$ and the effects of hypoxia on the generation of locomotor-like activity in the in vitro spinal cord of the neonatal mouse. Neuroscience 117:183-196. 